\title{
Critical Success Factors to Improve the Business Performance of Tea Drink Chains
}

\author{
Dyi-Cheng Chen ${ }^{1}$, Der-Fa Chen ${ }^{1, *}$, Shih-Ming Huang ${ }^{1}$, Mu-Jung Huang ${ }^{2, *}$, Wen-Jye Shyr ${ }^{1, *} \mathbb{C}$ \\ and Chien-Fu Chiou ${ }^{1}$
}

1 Department of Industrial Education and Technology, National Changhua University of Education, Changhua 500, Taiwan; dcchen@cc.ncue.edu.tw (D.-C.C.); hsm2014y@gmail.com (S.-M.H.); chenfu168@yahoo.com.tw (C.-F.C.)

2 College of Management, National Changhua University of Education, Changhua 500, Taiwan

* Correspondence: dfchen@cc.ncue.edu.tw (D.-F.C.); mjhuang@cc.ncue.edu.tw (M.-J.H.); shyrwj@cc.ncue.edu.tw (W.-J.S.)

Citation: Chen, D.-C.; Chen, D.-F.; Huang, S.-M.; Huang, M.-J.; Shyr, W.-J.; Chiou, C.-F. Critical Success Factors to Improve the Business Performance of Tea Drink Chains. Sustainability 2021, 13, 8953. https:// doi.org/10.3390/su13168953

Academic Editor: Paweł Bryła

Received: 23 June 2021

Accepted: 5 August 2021

Published: 10 August 2021

Publisher's Note: MDPI stays neutral with regard to jurisdictional claims in published maps and institutional affiliations.

Copyright: (c) 2021 by the authors. Licensee MDPI, Basel, Switzerland. This article is an open access article distributed under the terms and conditions of the Creative Commons Attribution (CC BY) license (https:/ / creativecommons.org/licenses/by/ $4.0 /)$.

\begin{abstract}
By determining critical success factors (CSFs), this study intends to identify indicators and offer suggestions for existing owners or operators to improve their critical works in business management, as well as for newcomers interested in investing or studying the chain business. To achieve the purpose of this study, document analysis, expert interviews, and the Delphi technique were used to verify that there are five-dimension indicators to explore the CSFs for tea drink chains. The critical success items in this study are as follows: (1) Regarding "brand image management", the most critical factors unanimously agreed by the professionals are the certification of raw materials and the guarantee of food safety, which are mainly affected by the recent food safety crisis. (2) Regarding "quality and cost control", the sub-items of raw material supplier's stability and timeliness are the most important factors. (3) Regarding the "location of business", the most important factors are the sub-items of visibility, convergence of people flow, and the structural consumption characteristics of the population in the area. Although these are not considered to be the most important factors in the questionnaires by professionals, the professors considered these sub-items to be the most critical factors in the dimension and should provide valuable references for CSFs. (4) Regarding "personnel training and customer satisfaction", the sub-item of maintaining hygiene in shop fronts is the most important critical factor, followed by the attitude and affinity of the staff, as well as their clothing, appearance, and cleanliness. (5) Regarding the "marketing mode and promotion mode", the two important sub-items include new product tasting and the irregular launch of new seasonal products.
\end{abstract}

Keywords: business performance; Delphi technique; critical success factors

\section{Introduction}

Mainly well-known for hand-held drinks such as the innovative "Bubble Tea", the business mode of tea drink chains [1,2] is very popular in Taiwan. Bustinza et al. [3] proposed a Business to Consumer (B2C) perspective. As they offer varied tastes, the drinks are highly popular among young people. Requiring minimal technique and having been eliminated and screened in the completely competitive market, in order for tea drink chains to expand continuously, they must have their own critical success factors (CSFs) [4,5] and operational mode. Critical success factors are those aspects that must be well-managed in order to achieve success. The results could guide managers in the implementation of effective key success factors in an effort to mitigate management problems in a very competitive sector [6]. Despite the continuous spread of COVID-19, some business operators continuously expand their investment to open franchised chain stores and even set up branches in Japan, Korea, European countries, and the U.S. [7]. The factors that are unique and critical in their businesses are worth exploring. As the tea drink chains often introduce new, fresh, customized, and innovative hand-held products to enhance their brand image, 
this study aims to explore the CSFs for the growth of tea drink chain companies. It also intends to discuss the CSFs [8] that enhance the brand image and the performance of franchised chains to generate higher profits.

In addition to business innovation, this study explored the CSFs for tea drink chains to achieve continuous development and expand their business scale. The CSFs identified by this study can provide reference for business operators or managers to rethink how to improve the critical works in management [9] and provide referential indicators and suggestions for future studies. Regarding the research methods, in addition to consulting relevant professors and conducting in-depth interviews with the business operators and managers of many well-known tea drink chain companies, this study summarized the valuable experiences and opinions of scholars and experts and adopted the Delphi Technique [10] to analyze the possible CSFs.

The IIBA [11] proposed guidance to identify business analysis knowledge areas that are generally recognized and accepted as good practice. Business analysis is a set of tasks, knowledge, and techniques required to identify business needs and determine solutions to business problems. Solutions often include a systems development component.

Petrillo et al. [12] proposed an Agile Reengineering Performance Model (ARPM) to serve as a valuable tool to facilitate a successful business process design with project management and intends to assist companies with their operate projects of transferring and optimizing production lines. They built a theoretical and practical framework to support the decision-making process in order to help companies optimize the reengineering production processes and improve management costs.

Tea culture is an essential part of Chinese tradition culture. Consumers have long established traditions of drinking tea and have developed a unique lifestyle based on the consumption of tea [13]. The tea culture among modern Chinese consumers particularly is shifting into an industry that is similar to that in other countries, especially Western countries, but with a broader offering of upscale and gourmet tea drinks. China's timehonored tradition of drinking tea is in transition from drinking traditional tea drinks, which focus on the taste of tea leaves, to a new style of tea drink. Furthermore, Chinese consumers tea-drinking habits are changing. Some younger consumers now perceive tea drinking not as a time-consuming tradition but as part of a cool and modern lifestyle [14]. The new-style tea drink is a large and growing market and as such has garnered considerable attention from entrepreneurs, investors, and chain outlet operators [15].

The tea drink chains have promising opportunities for producing in developing countries. Yet intense competition and low margins in some parts of the market make it all the more important for tea-producing countries to upgrade their position in tea drink chains as a means to stay competitive and reap development benefits $[16,17]$.

The scope of this study covers the tea drink chains in different areas of Taiwan [18], which are all well-known brands with headquarters in Taiwan and with at least 10 stores. The interviewees were either the franchise chain owners or the practical managers. By using literature discussion, an in-depth questionnaire survey, and expert interviews, this study analyzed and summarized the CSFs of the tea drink chains. In addition to innovation, a successful tea drink chain should be able to continuously improve and develop its business scope and expand its franchise scale and critical success factors (CSF), which is the topic of this study.

The tea-drinking history of Taiwan is long and people have been busy with the improvement of living standards in the past years. The number of people who eat outside is increasing gradually. The demand for tea cannot be ignored; it is not a slogan to drink a cup of the beverage every day. The amount of tea-drinking chain shops opening is increasing in order to obtain the market. To understand how to obtain a place in the market and uncover what the key critical success factors are, this study used dimensions from previous research, used questionnaires with specialists and managers, and used the Delphi technique method. 


\section{Literature Review}

\subsection{Chain Business Model}

After determining the study topic, this study collected the websites and webpages of relevant topics of what consumers tell waiters: Give me a latte and add some boba in, please. In more and more franchise stores, bubble milk tea has gained popularity; it has spread in Europe and the United States, and even entered the Middle East, and is now all over the world. Experts reached a consensus on tea drink chains about the relations between dimensions and guidelines by using the modified Delphi method. Finally, the contents of the questionnaire of the analytic network process (ANP) were confirmed using modified dimensions and guidelines. The experts then assessed the relative significance of the dimensions and the guidelines, referring to existing studies, that positively impact: (1) "brand loyalty", (2) "perceived quality/leadership" and (3) "brand association/differentiation" [19]. The conducted analysis, discussion of relevant interviews and reports, and related documents and records were collected.

A chain business model reflects that an enterprise creates, delivers, and captures values in concert with transaction partners [20]. Choosing the right business model helps a firm manage resources to deliver the best value to its customers, in terms of enterprise content, structure, and governance of transactions [21,22].

The drink chain business model is in a preliminary stage. On reflection of the lack of clarity of this concept, Benson-Rea et al. [23] investigated and believed that multiple business models coexist in the drink chain. Huemer [24] points out that different drink chains use different business models. Trkman et al. [25] indicated that a drink chain should use one business model. Combining the results of the above scholars and the connotation of the drink chain, such that the drink chain business model consists of the entire drink chain of each enterprise business model to meet the end customer's demand and the drink chain as a whole on how to integrate resources to meet these needs and generate profits.

The chain business model is a system of multiple components, such as value proposition, products and services, and value networks [26]. The business model's focus is a value proposition allowing stakeholders to create values in consideration of external and internal needs, for example, the environment, social, customers, shareholders, and suppliers. The interaction of factors enables each node in a drink chain to enhance flexibility and sustainability by adapting internal processes, providing products, improving employee skills, and appropriately linking them to external activities of the partners and customers [27-29].

\subsection{Business Performance}

Business performance management is the best known way of realizing and achieving the alignment of strategy and effective approach for excellent strategic execution, but its implementation is very challenging for many enterprises. Many enterprises lay more emphasis on the financial aspect of business performance management, forgetting there are more areas to be improved to achieve the execution and deployment of strategic goals. Ariyachandra and Frolick [30] described the main critical success factor for the success of the implementation of business performance.

A very strong support is required from the top management team in realizing a successful business performance for many enterprises and this is also supported by. In addition, some enterprises utilize a group of dedicated individuals or a key performance index (KPI) team to achieve the business process skills, while other enterprises make use of a business analyst who already has a sound understanding of the company business processes [31].

Understanding and enhancing customer involvement and communication in business performance management can also aid effective communication within the enterprise, which will also lead to better enterprise performance in facing the challenges of the current competitive market [32,33]. Reich and Benbasat [34] described that effective communication, which resulted from the integration of the IT and business processes, eventually led 
to a shared common understanding and a clear direction for alignment of the enterprise business strategic initiative.

The concept of IoT is based on the installation of a virtual platform that-through Radio Frequency Identification (RFID) tags, bar codes, wireless sensors (WS), and smart devices-combines all the data on production and service operations within the supply chain [35]. In this way, the need for physical contact is reduced and the system itself detects shortages, increased demand, stock position, and promptly sends signals to the downward members of the supply chain. This type of networking is especially emphasized in FMCG due to large daily fluctuations on the side of supply and demand. In the restaurant sector, geographic location is relevant for market segmentation, as customers value various attributes differently depending on store locations [36].

\subsection{Critical Success Factors}

Critical success factors [37] are one of the most important methods of information system planning and is a method of managing information systems' overall planning based on key factors to determine system information. The CSFs were developed through the theoretical lenses of five organizational theories, namely, stakeholder theory, resourcebased view theory, relational-view theory, innovation diffusion theory, and contingency (fit) theory [38]. From a theoretical point of view, a well-structured SIB creates an incentive structure that aligns the interests of all involved parties [39]. Carè et al. [40] identified and assessed three main groups of motivations, critical success factors, and risk factors by focusing on the private-sector SIB actors with the aim of understanding their motivations and their perceived main success drivers and risk factors.

Data were collected from 14 cases for the CSFs [41] of the chain business model using semi-structured interviews and were analyzed to identify a range of critical success factors and barriers $[8,9,42]$ that are discussed in 5 dimensions and 50 sub-items.

Through literature review and discussions with professors and professionals, 5 dimensions were selected to explore the CSFs for tea drink chains, namely "brand image management", "personnel training and customer satisfaction", "quality and cost control", "marketing mode and promotion mode", and "location of business". Three rounds of structured questionnaires by the Delphi Technique were completed by 12 professionals from well-known tea drink chains and 2 professors in Taiwan, and in-depth interviews and qualitative research were conducted.

\section{Methodology}

\subsection{Delphi Technique}

The Delphi Technique [43] has been widely used in various research areas, including curriculum planning and capability indicators. There are more than 10 Delphi technique experts, with the smallest group error and the highest credibility [44]. It can also be used to explore or understand the assumptions and related judgement in many disciplines. However, according to literature regarding the Delphi technique, there is no optimum number of professionals and professors required to reach a consensus. If the background knowledge of the Delphi technique is adopted, 10-15 professionals and professors will reach the standard of consensus number who chose those competencies they perceived as important, and a consensus was reached in accordance with the fuzzy Delphi method [45].

Figure 1 shows the steps to prepare the questionnaire by the Delphi technique. Through three rounds of Delphi questionnaires and Kolmogorov-Smirnov One Sample Testing, this study determined a total of 18 sub-items in the five dimensions of the CSFs. 


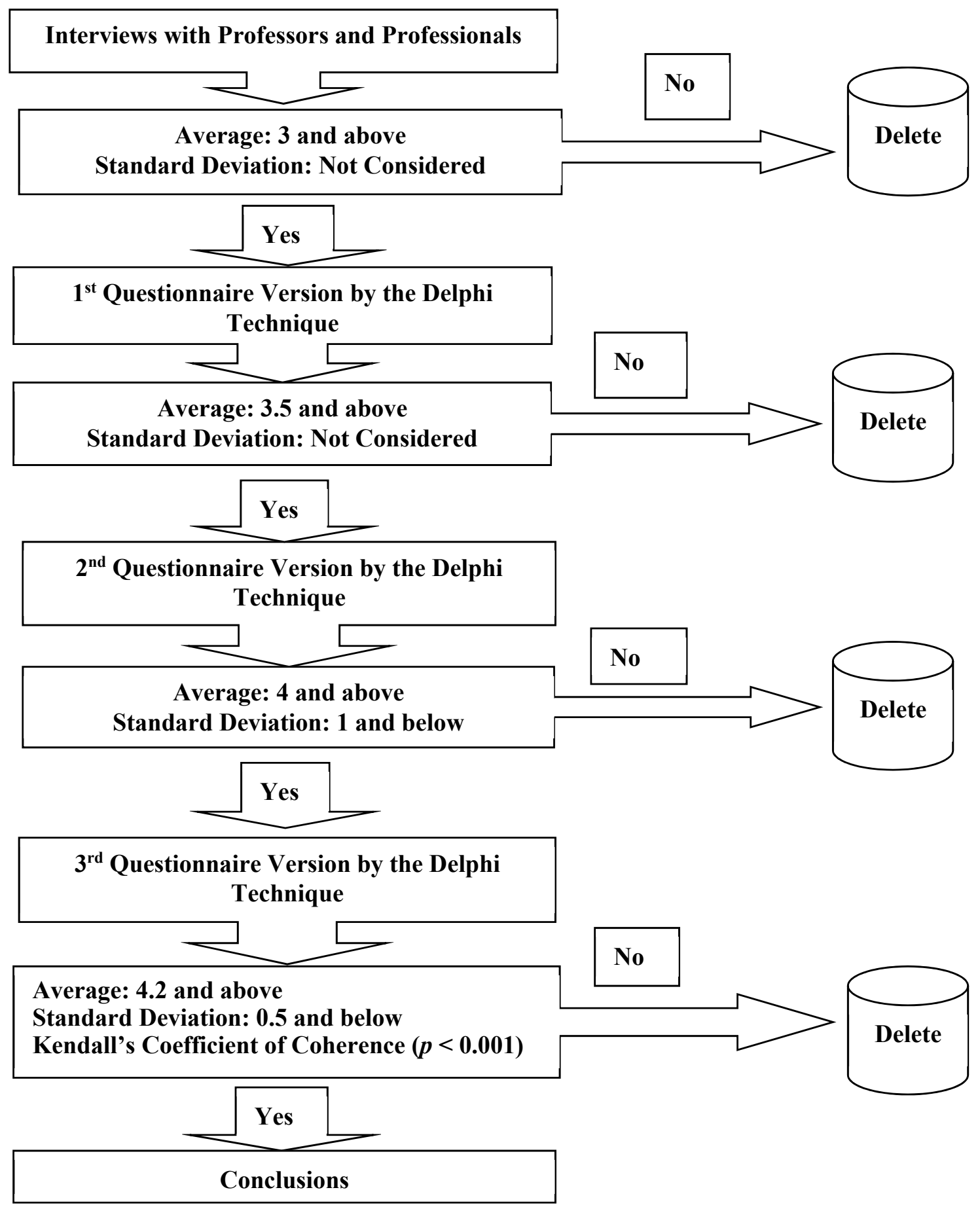

Figure 1. Steps to prepare the questionnaire by the Delphi technique.

\subsection{Instruments}

The research tool to collect the expert opinions of this study was a 5-point Likert scale, ranging from 5 (very important) to 1 (not important).

This study included two parts: in-depth interviews with scholars and experts and the questionnaire survey by the Delphi technique [46]. After 3 rounds of interviews with the scholars and experts by the Delphi technique, the CSFs of tea drink chains were analyzed and summarized. The relevant literature was reviewed, summarized, and sorted out, and the relevant structural factors of the topic were designed and proposed. The professors were invited to share their opinions, and then the sub-items of the critical factors were 
selected. Furthermore, the in-depth interviews were conducted to collect the experiences of senior managers of the tea drink chains. Based on the opinions of the scholars and experts, this study formulated the structured research questionnaire by the Delphi technique.

This study adopted qualitative and quantitative research methods to develop new product efforts that hinge on 16 critical factors in five areas [47]. Through in-depth and semi-open interview, the opinions of the scholars and experts were collected to design the first version of the questionnaire. The five dimensions of CSFs identified in this study were "brand image management", "quality and cost control" [48], "store location", "personnel training and customer satisfaction", and "marketing mode and promotion mode" [49]. According to the interview and statistics of the expert opinions, the research structure was determined and is summarized in Figure 2.

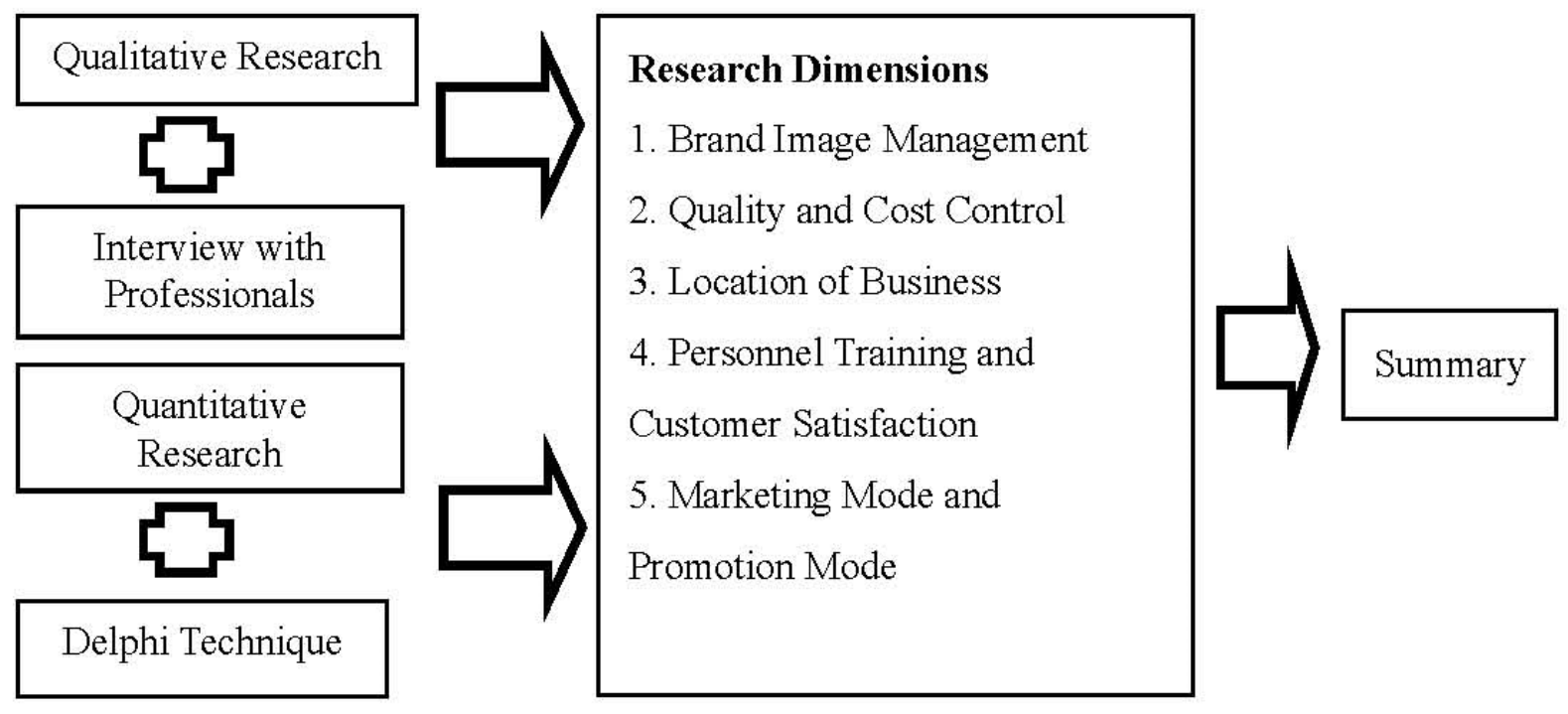

Figure 2. Research structure.

\subsection{Content Design of Questionnaire}

The CSFs of tea drink chains [50] mainly include five dimensions ("brand image management", "quality and cost control", "location of business", "personnel training and customer satisfaction", and "marketing mode and promotion mode") and fifty sub-items, and are summarized in Appendix A.

\subsection{Research Implementation}

The implementation part of this study was divided into three stages: (1) establishment of expert content validity, (2) implementation of a Delphi survey, and (3) data processing.

\subsubsection{Establishment of Expert Content Validity}

Based on the literature review and the discussion results of experts in the field of tea drink chains and business performance, a preliminary questionnaire for the construction of critical success factors to improve business performance was established. Then, the professional teachers of tea drink chain business performance in universities and colleges and the experts in the tea drink chain industry were interviewed to jointly review the literature discussion and the expert content validity review questionnaire, revise the questionnaire, and give advice on the questionnaire. Finally, according to the expert suggestions and opinions, the expert content validity review questionnaire was organized into the first Delphi questionnaire.

\subsubsection{Implementation of Delphi Survey}

In this study, according to the Delphi survey method and the questionnaire of the expert content validity review questionnaire, ten industrial experts and professional teach- 
ers related to the tea drink chains and business performance were invited to participate in the questionnaire survey [51-53]. Through questionnaire analysis, the consensus of the industry experts and professional teachers on the critical success factors were summarized. The investigation procedure using the Delphi survey method was as follows:

(1) Develop a Delphi questionnaire based on the expert content validity review questionnaire.

(2) Select experts in the field to become Delphi experts.

(3) Consult by telephone and determine the list of Delphi experts.

(4) Send the first Delphi questionnaire letters and the first Delphi questionnaires.

(5) Recover the first Delphi questionnaires, analyze the mode (Mo), mean (M), and standard deviation (SD) of each question, and modify the questionnaire into the second Delphi questionnaire.

(6) Send the second Delphi questionnaire letters and second Delphi questionnaires.

(7) Recover the second Delphi questionnaires, analyze the Mo, M, and SD of each question, and modify the questionnaire into the third Delphi questionnaire.

(8) Send the third Delphi questionnaire letters and the third Delphi questionnaires.

(9) Recover the third Delphi questionnaires and analyze the Mo, M, SD, and expert consistency of each question.

Field experts were invited to participate in three rounds of the Delphi questionnaire survey. All the questionnaires sent were recovered. After the questionnaires were recovered, data analysis was conducted.

\subsubsection{Data Processing}

Through the three rounds of the Delphi questionnaire survey, the data were analyzed through statistical software to confirm the expert consistency and to summarize the critical success factors to improve the business performance.

\section{Results}

\section{Test the Statistics}

A Kendall's W test of the questionnaire was used to evaluate the consistency of the 12 professionals. Table 1 shows the statistics of Kendall's coefficient of concordance. With a Chi-square of 92.633, the coefficient of concordance of Kendall was $0.000(p<0.001)$, which suggests consistent expert opinions.

Table 1. The Kendall's coefficient of concordance.

\begin{tabular}{cc}
\hline Number $(\mathbf{N})$ & $\mathbf{1 2}$ \\
\hline Kendall's W test & 0.266 \\
Chi-square & 92.633 \\
Degree of freedom & 29 \\
Asymptotic significance & 0.000 \\
\hline
\end{tabular}

After 3 rounds of the structured questionnaire by the Delphi Technique and the collection of the opinions of 2 professors from in-depth interviews and 12 experts from questionnaires, this study conducted Kolmogorov-Smirnov One Sample Z-tests on the contents of the five dimensions. The results showed that the expert opinions all reached a significant level $(p<0.01)$, suggesting that the third version of the questionnaire was more reliable than the second version. The test results of the average (M), mode (Mo), and standard deviation (SD) of the sub-items by K-S Z-tests are listed in Table 2. 
Table 2. The statistical analysis by the Delphi technique.

\begin{tabular}{|c|c|c|c|c|c|c|}
\hline No. & Item & $\mathbf{M}$ & Mo & SD & K-S Z-Test & Choice \\
\hline \multicolumn{7}{|c|}{ I. Factors of Brand Image Management } \\
\hline $1-1$ & Store design and decoration appearance & 4.5 & $5(4)$ & 0.50 & $1.732 * *$ & Keep \\
\hline $1-2$ & Advertisement and media publicity & 4.08 & 4 & 0.62 & 1.155 & Delete \\
\hline $1-3$ & Story of brand management & 4.42 & 5 & 0.63 & $1.732^{* *}$ & Delete \\
\hline $1-4$ & Recognition of brand logo & 4.83 & 5 & 0.37 & $2.887^{* *}$ & Keep \\
\hline $1-6$ & Theory and mission of brand & 4.25 & 5 & 0.61 & 1.155 & Delete \\
\hline $1-7$ & Differentiation and advantages of brand & 4.83 & 5 & 0.37 & $2.887^{* *}$ & Keep \\
\hline $1-8$ & Characteristics and spirit of brand & 4.42 & 5 & 0.63 & $1.732^{* *}$ & Delete \\
\hline $1-9$ & $\begin{array}{l}\text { Quality certifications of raw materials purchased } \\
\text { and guarantee of food safety }\end{array}$ & 5 & 5 & 0.00 & $2.887^{* *}$ & \\
\hline $1-10$ & Taste and uniqueness of drinks & 4.67 & 5 & 0.47 & $2.309 * *$ & \\
\hline $1-12$ & $\begin{array}{l}\text { Choice between investment in self-operated } \\
\text { stores and franchise stores }\end{array}$ & 4.25 & 4 & 0.43 & $2.598^{* *}$ & Keep \\
\hline \multicolumn{7}{|c|}{ II. Factors of Quality and Cost Control } \\
\hline $2-1$ & $\begin{array}{l}\text { Direct material costs include tea, sugar, creamer, } \\
\text { milk, etc. }\end{array}$ & 4.42 & 4 & 0.49 & $2.021 * *$ & Keep \\
\hline $2-2$ & $\begin{array}{l}\text { Direct labor costs include production of tea } \\
\text { drinks and salary of the counter attendants }\end{array}$ & 4.33 & 4 & 0.47 & $2.309^{* *}$ & Keep \\
\hline $2-3$ & $\begin{array}{l}\text { Indirect costs include rent, insurance, and } \\
\text { depreciation }\end{array}$ & 4.08 & 4 & 0.62 & 1.155 & Delete \\
\hline $2-5$ & $\begin{array}{l}\text { Costs include water purification and } \\
\text { refrigeration equipment, POS equipment, } \\
\text { tea-making equipment, sealing machines, etc. }\end{array}$ & 3.83 & 4 & 0.36 & $2.309^{* *}$ & Delete \\
\hline $2-9$ & $\begin{array}{l}\text { Expenses of food safety inspection and staff } \\
\text { education and training }\end{array}$ & 4.5 & $5(4)$ & 0.50 & $1.732 * *$ & Keep \\
\hline $2-10$ & Stability and timeliness of raw material suppliers & 4.67 & 5 & 0.47 & $2.309 * *$ & Keep \\
\hline $2-11$ & $\begin{array}{l}\text { SOP planning and implementation of the } \\
\text { production flow }\end{array}$ & 4.5 & 5 & 0.50 & $1.732 * *$ & Keep \\
\hline $2-12$ & Competitiveness with peers & 4.42 & $5(4)$ & 0.63 & $1.732 * *$ & Delete \\
\hline \multicolumn{7}{|c|}{ III. Factors of Location of Business } \\
\hline $3-9$ & \multicolumn{2}{|l|}{ Visibility of the location of business } & \multicolumn{2}{|c|}{$\begin{array}{l}\text { Qualitative } \\
\text { Research }\end{array}$} & \multicolumn{2}{|c|}{ Opinions of Professors } \\
\hline $3-10$ & \multicolumn{2}{|l|}{ Convergence of people flow } & \multicolumn{2}{|c|}{$\begin{array}{l}\text { Qualitative } \\
\text { Research }\end{array}$} & \multicolumn{2}{|c|}{ Opinions of Professors } \\
\hline $3-11$ & \multicolumn{2}{|c|}{$\begin{array}{l}\text { Structural consumption characteristics of the population in } \\
\text { the area }\end{array}$} & \multicolumn{2}{|c|}{$\begin{array}{l}\text { Qualitative } \\
\text { Research }\end{array}$} & \multicolumn{2}{|c|}{ Opinions of Professors } \\
\hline \multicolumn{7}{|c|}{ (The 3 items above are the supplementary items of the in-depth interview with professors [19]) } \\
\hline $4-1$ & Professional training of staff & 4.58 & 5 & 0.49 & $2.021 * *$ & Keep \\
\hline $4-2$ & Dress, appearance, and cleanliness of staff & 4.67 & 5 & 0.47 & $2.309^{* *}$ & Keep \\
\hline $4-3$ & Service attitude and affinity of staff & 4.75 & 5 & 0.43 & $2.887^{* *}$ & Keep \\
\hline $4-5$ & Strengthen the empathy of service quality & 4.58 & 5 & 0.63 & $2.309^{* *}$ & Delete \\
\hline $4-7$ & $\begin{array}{l}\text { Maintain the cleanliness and hygiene of store at } \\
\text { all times }\end{array}$ & 4.83 & 5 & 0.37 & $2.887^{* *}$ & Keep \\
\hline $4-8$ & Turnover rate of staff & 4.25 & 4 & 0.43 & $2.598 * *$ & Keep \\
\hline $4-9$ & Meeting customer needs and customization & 4.17 & 4 & 0.66 & 1.155 & Delete \\
\hline \multicolumn{7}{|c|}{ V. Factors of Marking Mode and Promotion Mode } \\
\hline $5-1$ & $\begin{array}{c}\text { New product launch promotion and tasting } \\
\text { activities }\end{array}$ & 4.33 & 4 & 0.47 & $2.309^{* *}$ & Keep \\
\hline $5-2$ & Irregular launch of new seasonal products & 4.33 & 4 & 0.47 & $2.309^{* *}$ & Keep \\
\hline
\end{tabular}

${ }^{* *} p<0.01$.

Based on the third Delphi survey, a total of 18 sub-items were identified as CSFs to improve the performance of tea drink chains and the priority is as follows in Table 3. 
Table 3. Priority and test of CSFs of business performance.

\begin{tabular}{|c|c|c|c|c|c|}
\hline Priority & Item & $\mathbf{M}$ & Mo & SD & Z-Test \\
\hline 1 & $\begin{array}{l}\text { 1-9 Quality certifications of raw materials purchased and } \\
\text { guarantee of food safety }\end{array}$ & 5 & 5 & 0.00 & $2.887^{* *}$ \\
\hline 2 & 1-4 Recognition of brand logo & 4.83 & 5 & 0.37 & $2.887^{* *}$ \\
\hline 3 & 1-7 Differentiation and advantages of brand & 4.83 & 5 & 0.37 & $2.887^{* *}$ \\
\hline 4 & 4-7 Maintain the cleanliness and hygiene of store at all times & 4.83 & 5 & 0.37 & $2.887 * *$ \\
\hline 5 & 4-3 Service attitude and affinity of staff & 4.75 & 5 & 0.43 & $2.887^{* *}$ \\
\hline 6 & 1-10 Taste and uniqueness of drinks & 4.67 & 5 & 0.47 & $2.309 * *$ \\
\hline 7 & $2-10$ Stability and timeliness of raw material suppliers & 4.67 & 5 & 0.47 & $2.309 * *$ \\
\hline 8 & 4-2 Dress, appearance, and cleanliness of staff & 4.67 & 5 & 0.47 & $2.309 * *$ \\
\hline 9 & 4-1 Professional training of staff & 4.58 & 5 & 0.49 & $2.021 * *$ \\
\hline 10 & 1-1 Store design and decoration appearance & 4.5 & $5(4)$ & 0.50 & $1.732 * *$ \\
\hline 11 & 2-11 SOP planning and implementation of the production flow & 4.5 & $5(4)$ & 0.50 & $1.732 * *$ \\
\hline 12 & $\begin{array}{l}\text { 2-9 Expenses of food safety inspection, staff education, } \\
\text { and training }\end{array}$ & 4.5 & $5(4)$ & 0.50 & $1.732 * *$ \\
\hline 13 & 2-1 Direct material costs include tea, sugar, creamer, milk, etc. & 4.42 & 4 & 0.49 & $2.021 * *$ \\
\hline 14 & $\begin{array}{l}\text { 2-2 Direct labor costs include production of tea drinks and } \\
\text { salary of the counter attendants }\end{array}$ & 4.33 & 4 & 0.47 & $2.309 * *$ \\
\hline 15 & 5-1 New product launch promotion and tasting activities & 4.33 & 4 & 0.47 & $2.309 * *$ \\
\hline 16 & 5-2 Irregular launch of new seasonal products & 4.33 & 4 & 0.47 & $2.309 * *$ \\
\hline 17 & $4-8$ Turnover rate of staff & 4.25 & 4 & 0.43 & $2.598^{* *}$ \\
\hline 18 & $\begin{array}{l}\text { 1-12 Choice between investment in self-operated stores and } \\
\text { franchise stores }\end{array}$ & 4.25 & 4 & 0.43 & $2.598 * *$ \\
\hline
\end{tabular}

Based on the third Delphi survey, 18 sub-items were identified in total as CSFs to improve the performance of tea drink chains as follows:

(1) For the sub-item of the quality certification of raw materials purchased and the guarantee of food safety, the average mean was 5 , the mode was 5 , and the standard deviation was 0 . This shows that all of the professionals believed that this item is very significant.

(2) For the sub-item of the recognition of the brand logo, the average mean was 4.83, the mode was 5 , and the standard deviation was 0.37 . This means that $84 \%$ of the professionals believed that this item is very significant and $16 \%$ believed it is significant.

(3) For the sub-item of the differentiation and advantages of brand, the average mean was 4.83 , the mode was 5 , and the standard deviation was 0.37 . Thus, $84 \%$ of the professionals believed that this item is very significant and $16 \%$ believed it is significant.

(4) For the sub-item of maintaining the cleanliness and hygiene of the store at all times, the average mean was 4.83 , the mode was 5 , and the standard deviation was 0.37 . This implies that $84 \%$ of the professionals believed that this item is very significant and $16 \%$ believed it is significant.

(5) For the sub-item of service attitude and the affinity of staff, the average mean was 4.75 , the mode was 5 , and the standard deviation was 0.43 . This denotes that $75 \%$ of the professionals believed that this item is very significant and $25 \%$ believed it is significant.

(6) For the sub-item of the taste and uniqueness of drinks, the average mean was 4.67, the mode was 5 , and the standard deviation was 0.47 . Thus, $67 \%$ of the professionals believed that this item is very significant and $33 \%$ believed it is significant.

(7) For the sub-item of the stability and timeliness of raw material suppliers, the average mean was 4.67 , the mode was 5 , and the standard deviation was 0.47 . We saw that $67 \%$ of the professionals believed that this item is very significant and $33 \%$ believed it is significant.

(8) For the sub-item of the dress, appearance, and cleanliness of staff, the average mean was 4.67 , the mode was 5 , and the standard deviation was 0.47 . This shows that $67 \%$ 
of the professionals believed that this item is very significant and 33\% believed it is significant.

(9) For the sub-item of the professional training of staff, the average mean was 4.58 , the mode was 5 , and the standard deviation was 0.49 . This means that $42 \%$ of the professionals believed that this item is very significant and $58 \%$ believed it is significant.

(10) For the sub-item of store design and decoration appearance, the average mean was 4.5 , the mode was 5(4), and the standard deviation was 0.5 . This denotes that $50 \%$ of the professionals believed that this item is very significant and $50 \%$ believed it is significant.

(11) For the sub-item of SOP planning and the implementation of the production flow, the average mean was 4.5 , the mode was 5(4), and the standard deviation was 0.5 . Therefore, $50 \%$ of the professionals believed that this item is very significant and $50 \%$ believed it is significant.

(12) For the sub-item of the expenses of food safety inspections, staff education and training, the average mean was 4.5 , the mode was 5(4), and the standard deviation was 0.5 . We saw that $50 \%$ of the professionals believed that this item is very significant and $50 \%$ believed it is significant.

(13) For the sub-item of the direct material costs including tea, sugar, creamer, and milk, the average mean was 4.42 , the mode was 4 , and the standard deviation was 0.49 . Overall, $42 \%$ of the professionals believed that this item is very significant and $58 \%$ believed it is significant.

(14) For the sub-item of direct labor costs that include the production of tea drinks and salaries of counter attendants, the average mean was 4.33 , the mode was 4 , and the standard deviation was 0.47 . This implies that $33 \%$ of the professionals believed that this item is very significant and $67 \%$ believed it is significant.

(15) For the sub-item of new product launch promotions and tasting activities, the average mean was 4.33 , the mode was 4 , and the standard deviation was 0.47 . This means that $33 \%$ of the professionals believed that this item is very significant and $67 \%$ believed it is significant.

(16) For the sub-item of the irregular launch of new seasonal products, the average mean was 4.33 , the mode was 4 , and the standard deviation was 0.47 . We saw that $33 \%$ of the professionals believed that this item is very significant and $67 \%$ believed it is significant.

(17) For the sub-item of the turnover rate of staff, the average mean was 4.25 , the mode was 4 , and the standard deviation was 0.43 . Overall, $25 \%$ of the professionals believed that this item is very significant and $75 \%$ believed it is significant.

(18) For the sub-item of the choice of investment in self-operated stores and franchise stores, the average mean was 4.25 , the mode was 4 , and the standard deviation was 0.43 . Therefore, $25 \%$ of the professionals believed that this item is very significant and $75 \%$ believed it is significant.

\section{Discussions}

The COVID-19 pandemic has affected the traditional 4Ps (product, price, place, and promotion) of marketing strategy that operate in the brick-and-mortar business environment. Online shopping with delivery has emerged as a new business model. However, these tea drink chain stores are required to pay as high as $32-42 \%$ of the selling price to the distributors under the new business model. The cost-benefit analysis under the new business model finds that online shopping with delivery becomes essential. Future researchers are suggested to focus not only on the CSFs of the brick-and-mortar business, but also on the integrated solution that includes SWOT analysis, POS, and AI payment for the online shopping business model. Additionally, KPI and MoSCow analyses should be considered to reflect the change of the market trend [11,12,54,55]. 
Lee and Liao [13] found that Chinese tea beverage brands pursue various goals, such as quenching thirst, attractive advertising, or reliable quality to develop their positions. Brand positioning implies that consumers remember particular information conveyed by the brand. Consumers' brand awareness attributes, potential market demand, and brand competition conditions were illustrated. Christopher and Holweg [56] proposed that as globalization and informatization continue to advance, competition is also intensifying, and corporate competition has evolved into a competition among drink chains. Drink chains cannot achieve sustainable competitive advantage simply by relying on existing resources and capabilities. Lin and Xiong [57] built a chain business model and critical success factors that match the market environment, which is important for the sustainable development of the drink chain.

This study examined the characteristics and evolution of the multi-stage tea drink chain business model and critical success factors through the Delphi technique and answered the tea drink chain focus enterprise on how to develop dynamic capabilities to cope with the rapidly changing environment and customer needs.

This study made a few theoretical contributions. Firstly, we extended the chain business model and critical success factors from enterprise to a tea drink chain level. By collecting historical data and interviews, we presented the critical success factors to improve the business performance of the tea drink chain. Secondly, we extended the analysis of the five-dimension success factors of tea drink chain business model. Zott and Amit [20] proposed that the chain business model and critical success factors are the decisive source for tea drink chains, such as for the enterprise itself, upstream suppliers, partners and downstream customers, and its evolution has become the focus of attention for drink chains. Huemer [24] proposed different enterprises in the tea drink chain use different business models and the tea drink chain can be seen as the integration of the business models. Based on the influence of customer-driven innovation and dynamic capability development, our research has dynamically summarized the tea drink chain business model's innovation.

This study has important management implications. First, enterprises need to pay attention to their own business models, the tea drink chain business model and critical success factors to align the whole chain to meet the final consumers' demands. Second, focal enterprises can shape the tea drink chain by orchestrating the tea drink chain members to obtain the needed resources and capabilities $[29,58]$.

\section{Conclusions}

This study adopted qualitative and quantitative research methods to develop new product efforts that hinge on critical success factors. Through in-depth and semi-open interviews, the opinions of scholars and experts were collected to design the first version of the questionnaire. The five dimensions of CSFs identified in this study were "brand image management", "quality and cost control", "location of business", "personnel training and customer satisfaction", and "marketing mode and promotion mode".

This study used the Delphi technique method, where the contents of critical success factors (CSFs) detail and offer suggestions for existing owners or operators to improve their critical works in business management, as well as for newcomers interested in investing or studying the chain business.

Regarding the sub-items of critical success factors from all dimensions, the results in the order of the research implementation were obtained. This study identified 18 critical success factors to improve the business performance of tea drink chains for incorporation within the curriculum of management education. These critical success factors can be divided into: (1) "brand image management" (6 items), (2) "quality and cost control" (5 items), (3) "personnel training and customer satisfaction" (5 items), and (4) "marketing mode and promotion mode" (2 items).

The conclusion of this study is as follows: (1) "Personnel training and customer satisfaction" was the most important critical success factor. It should focus the training 
for quality and the requirement of a good attitude toward customers. All items should influence the will of customers to consume again. (2) The "brand image management" is like a spiritual indicator that represents the tea drink chain. People refer to this brand and know which chain enterprise it is, meaning the brand image managing is successful. It can represent the spirit of the chain enterprise and have good quality at the same time. (3) The chain tea-drinking stores with high "quality and cost control" such as decoration cost, personnel cost, equipment cost, and water or electricity cost. Quality and cost control cannot be ignored with increasing income and profit. A centralized purchasing system should be used efficiently and can help chain stores save time and simplify processes to copy many models to obtain the market. (4) "Marketing mode and promotion mode" reach their results by using the propaganda of media and newspapers. The display and type of goods can reach their goal by marketing. (5) The "location of business" can be evaluated on other kinds of competition styles from traffic conditions. It is analyzed to determine the advantage of a location via influencing factors.

Author Contributions: All authors contributed meaningfully to this study. M.-J.H., D.-F.C. and S.-M.H.-research topic; D.-C.C., S.-M.H. and M.-J.H.- data acquisition and analysis; D.-F.C., S.-M.H., M.-J.H. and W.-J.S.-methodology support; S.-M.H., D.-C.C., W.-J.S. and M.-J.H.-original draft preparation; D.-F.C., C.-F.C. and W.-J.S.-writing review and editing. All authors have read and agreed to the published version of the manuscript.

Funding: This research received no external funding.

Institutional Review Board Statement: Not applicable.

Informed Consent Statement: Not applicable.

Data Availability Statement: Not applicable.

Conflicts of Interest: The authors declare no conflict of interest.

\section{Appendix A. Items of Critical Success Factors}

\section{CSFs for Brand Image Management: 12 Sub-items}

1-1 Store design and decoration appearance

1-2 Advertisement and media publicity

1-3 Story of brand management

1-4 Recognition of brand logo

1-5 Staff uniform and design of advertising banner

1-6 Theory and mission of brand

1-7 Differentiation and advantages of brand

1-8 Characteristics and spirit of brand

1-9 Quality certifications of raw materials purchased and guarantee of food safety

1-10 Taste and uniqueness of drinks

1-11 Requirements of franchise mechanism

1-12 Choice between investment in self-operated stores and franchise stores

\section{CSFs of Quality and Cost Control: 12 Sub-items}

2-1 Direct material costs include tea, sugar, creamer, milk, etc.

2-2 Direct labor costs include production of tea drinks and salary of the counter attendants

2-3 Indirect costs include rent, insurance, and depreciation

2-4 Indirect labor costs include accounting, production, warehouse management, and graphic design 
2-5 Costs include water purification and refrigeration equipment, POS equipment, tea-making equipment, sealing machines, etc.

2-6 Other miscellaneous expenses for management, marketing, and business operation

2-7 Fixed costs of headquarters and warehouse management

2-8 Performance award and dividend system

2-9 Expenses of food safety inspection, and staff education and training

2-10 Stability and timeliness of raw material suppliers

2-11 SOP planning and implementation of the production flow

2-12 Competitiveness with peers

\section{CSFs of Location of Business: 8 Sub-items}

3-1 Area of shopfronts

3-2 Rent level of stores or stalls

3-3 Adjacent to road or shopfront located at the intersection of two roads

3-4 Near to traditional market, park, or school

3-5 There are competitors nearby

3-6 There are stores in five-foot way of commercial street

3-7 Near to scenic sport or night markets

3-8 Collective residential community, enterprise office building, or factory concentration area

\section{CSFs of Personnel training and Customer Satisfaction: 9 Sub-items}

4-1 Professional training of staff

4-2 Dress, appearance, and cleanliness of staff

4-3 Service attitude and affinity of staff

4-4 Ability to respond to customer complaints

4-5 Strengthen the empathy of service quality

4-6 Proficiency in completing orders

4-7 Maintain the cleanliness and hygiene of store at all times

4-8 Turnover rate of staff

4-9 Meeting customer needs and customization

\section{CSFs of Marketing Mode and Promotion Mode: 9 Sub-items}

5-1 New product launch promotion and tasting activities

5-2 Irregular launch of new seasonal products

5-3 Irregular promotions that offer double the quantity of the product

5-4 Change packing capacity and pricing classification mode

5-5 Promotion mode of adding materials without increasing price (e.g., add "pearl" and milk for free)

5-6 Using a point collection card to give one cup free after buying a certain number of drinks

5-7 Offer prepayment to card for discount or preferential price

5-8 Discount for using environment friendly cups and containers brought by customers

5-9 Promotions of special festivals or in cooperation with local activities 


\section{References}

1. Ma, Y.F. The impact of Perceived Organizational Support on Franchisee Satisfaction and Contract Termination Intentions: The Mediating Role of Perceived Insider Status. Master's Thesis, Tunghai University, Taiwan, 2012.

2. Qiu, R.T. Study on the Business Strategy of Take-Out Chain Beverage Industry-Taking Dayuanzi as an Example. Master's Thesis, Tunghai University, Taiwan, 2015.

3. Bustinza, O.F.; Parry, G.C.; Vendrell-Herrero, F. Supply and demand chain management: The effect of adding services to product offerings. Supply Chain Manag. 2013, 18, 618-629. [CrossRef]

4. Bender, K.W. Process innovation-Case study of critical success factors. Eng. Manag. J. 2000, 12, 17-24. [CrossRef]

5. Brotherton, B. Critical success factors in UK budget hotel operations. Int. J. Oper. Prod. Manag. 2004, 24, 944-969. [CrossRef]

6. Marais, M.; Plessis, E.; Saayman, M. A review on critical success factors in tourism. J. Hosp. Tour. Manag. 2017, 31, 1-12. [CrossRef]

7. Zeng, Y.Y. Drank tens of billions of business opportunities: Taiwan's hand-cranked tea drinks to enter the world. Watch. Mag. 2015, 6, 36 .

8. Dora, M.; Kumar, M.; Van Goubergen, D.; Molnar, A.; Gellynck, X. Operational performance and critical success factors of lean manufacturing in European food processing SMEs. Trends Food Sci. Technol. 2013, 31, 156-164. [CrossRef]

9. Long, T.B.; Looijen, A.; Blok, V. Critical success factors for the transition to business models for sustainability in the food and beverage industry in the Netherlands. J. Clean. Prod. 2018, 175, 82-95. [CrossRef]

10. Wu, Q.S.; Lin, T.Y. Virtuousness. Taiwan Educ. Res. Mon. 2001, 92, 127.

11. IIBA (International Institute of Business Analysis). A Guide to the Business Analysis Body of Knowledge; International Institute of Business Analysis: Pickering, ON, Canada, 2015; Available online: https:/ /cs.anu.edu.au/courses/comp3120/public_docs/ BOKV1_6.pdf (accessed on 12 June 2021).

12. Petrillo, A.; DiBona, G.; Forcina, A.; Silvestri, A. Building excellence through the agile reengineering performance model (ARPM): A strategic business model for organizations. Bus. Process Manag. J. 2018, 24, 128-157. [CrossRef]

13. Lee, C.W.; Liao, C.S. The effects of consumer preferences and perceptions of Chinese tea beverages on brand positioning strategies. Br. Food J. 2009, 111, 80-96. [CrossRef]

14. Li, P. Mine water problems and solutions in China. Mine Water Environ. 2018, 37, 217-221. [CrossRef]

15. Wang, Z.R.; Marjerison, R.K. Factors influencing consumers' purchase intentions towards made-to-order tea drinks in China. Int. J. Food Beverage Manuf. Bus. Models 2019, 4, 29-52. [CrossRef]

16. Kaplinsky, R.; Morris, M. Thinning and thickening: Productive sector policies in the era of global value chains. Eur. J. Dev. Res. 2016, 28, 625-645. [CrossRef]

17. Bair, J.; Gereffi, G. Upgrading, uneven development, and jobs in the North American apparel industry. Glob. Netw. 2003, 3, 143-169. [CrossRef]

18. Chen, C.M.; Lin, F.J.; Wu, P.C. Research on the key success factors affecting the stable development of organic agriculture in Yilan County. Agric. Econ. Ser. 2018, 24, 31-60.

19. Huang, Y.F.; Lee, S.S.; Tsai, H.J.; Chang, T.C. A study of relationship among product information disclosure, brand equity and cause-related marketing: A case of takeout beverage chain and franchises industry. Chaoyang Commer. Manag. Rev. 2013, 12, 65-90.

20. Zott, C.; Amit, R. Business model design: An activity system perspective. Long Range Plan. 2010, 43, 216-226. [CrossRef]

21. Teece, D.J. Explicating dynamic capabilities: The nature and microfoundations of (sustainable) enterprise performance. Strateg. Manag. J. 2007, 28, 1319-1350. [CrossRef]

22. Zott, C.; Amit, R.; Massa, L. The business model: Recent developments and future research. J. Manag. 2011, 37, $1019-1042$.

23. Benson-Rea, M.; Brodie, R.J.; Sima, H. The plurality of co-existing business models: Investigating the complexity of value drivers. Ind. Mark. Manag. 2013, 42, 717-729. [CrossRef]

24. Huemer, L. Unchained from the chain: Drink management from a logistics service provider perspective. J. Bus. Res. 2012, 65, 258-264. [CrossRef]

25. Trkman, P.; Budler, M.; Groznik, A. A business model approach to drink chain management. Drink Chain Manag. 2015, 20, 587-602.

26. Hwang, J.; Christensen, C.M. Disruptive innovation in health care delivery: A framework for business-model innovation. Health Aff. 2008, 27, 1329-1335. [CrossRef]

27. Kamal, M.M.; Irani, Z. Analysing drink chain integration through a systematic literature review: A normative perspective. Drink Chain Manag. 2014, 19, 523-557.

28. Wiengarten, F.; Longoni, A. A nuanced view on drink chain integration: A coordinative and collaborative approach to operational and sustainability performance improvement. Drink Chain Manag. 2015, 20, 139-150.

29. Sun, Y.; Gong, Y.; Zhang, Y.; Jia, F.; Shi, Y. User-driven drink chain business model innovation: The role of dynamic capabilities. Corp. Soc. Responsib. Environ. Manag. 2021, 28, 1157-1170. [CrossRef]

30. Ariyachandra, T.R.; Frolick, M.N. Critical success factors in business performance management-striving for success. Inf. Syst. Manag. 2008, 25, 113-120. [CrossRef]

31. Eckerson, W. Performance Dashboards: Measuring, Monitoring and Managing Your Business; John Wiley \& Sons: Hoboken, NJ, USA, 2010.

32. Boynton, A.C.; Robert, W.Z. An assessment of critical success factors. Sloan Manag. Rev. 1984, 25, 17-27. 
33. Mohan, S. Value Chain Upgrading for Competitiveness and Sustainability: A Comparative Study of Tea Value Chains in Kenya, Sri Lanka and Nepal; International Centre for Trade and Sustainable Development (ICTSD): Geneva, Switzerland, 2018; Available online: https:/ / www.researchgate.net/publication/323425108_Value_Chain_Upgrading_for_Competitiveness_and_Sustainability_ A_Comparative_Study_of_Tea_Value_Chains_in_Kenya_Sri_Lanka_and_Nepal (accessed on 20 July 2021).

34. Reich, B.H.; Benbasat, I. Factors that influence the social dimension of alignment between business and information technology objectives. MIS Q. 2000, 24, 81-113. [CrossRef]

35. Khan, M.A.; Salah, K. IoT security: Review, blockchain solutions, and open challenges. Future Gener. Comput. Syst. 2018, 82, 395-411. [CrossRef]

36. Kukard, W.; Wood, L. Consumers' perceptions of item-level RFID use in FMCG: A balanced perspective of benefits and risks. J. Glob. Inf. Manag. 2017, 25, 21-42. [CrossRef]

37. Zani, W. The Computer Utility. Calif. Manag. Rev. 1970, 13, 31-37. [CrossRef]

38. Tran, T.M.T.; Yuen, K.F.; Li, K.X.; Balci, G.; Ma, F. A theory-driven identification and ranking of the critical success factors of sustainable shipping anagement. J. Clean. Prod. 2020, 243, 118401. [CrossRef]

39. Maier, F.; Meyer, M. Social impact bonds and the perils of aligned interests. Adm. Sci. 2017, 7, 24. [CrossRef]

40. Carè, R.; Rania, F.; De Lisa, R. Critical success factors, motivations, and risks in social impact bonds. Sustainability 2020, $12,7291$. [CrossRef]

41. Abdel-Fattah, M.A. A model to evaluate the benefits of applying BPR methodology. Int. J. Adv. Res. Comput. Sci. Softw. Eng. 2015, 5, 101-107.

42. Chiu, C.T. Advanced education and mortality compression in the United States. EurAmerica 2017, 47, 143-175.

43. Delbecq, A.L. Group Techniques for Program Planning: A Guide to Nominal Group and Delphi Processes; Scott, Foresman and Company: Upper Saddle River, NJ, USA, 1975.

44. Woudenberg, F. An evaluation of Delphi. Technol. Forecast. Soc. Chang. 1991, 40, 131-150. [CrossRef]

45. Murry, J.W.; Hammons, J.O. Delphi: A versatile methodology for conducting qualitative research. Rev. High. Educ. 1995, 18, 423-436. [CrossRef]

46. Lei, J.; Huang, W.Y. Pragmatic professionalism: A fuzzy Delphi study on the competencies of social workers in Guangzhou, China. Br. J. Soc. Work 2018, 48, 505-524. [CrossRef]

47. Lai, K.W. The role of value satisfaction and commitment in the impact of service quality on customer loyalty in Hong Kong-style tea restaurants. Cornell Hotel Q. 2015, 56, 118-138. [CrossRef]

48. Sean, S. Predictive indicators of relationship quality and loyalty in the chain restaurant industry. Cornell Hotel Q. 2010, 51, 251-267.

49. Lester, D.H. Critical success factors for new product development. Res. Technol. Manag. 2016, 41, 36-43. [CrossRef]

50. Chen, Z.S. An Empirical Research of Key Success Factors for the Chain Tea-Drinking Store. Master's Thesis, National Cheng Kung University, Taiwan, 2011.

51. Lin, C.T.; Hung, K.P.; Hu, S.H. A decision-making model for evaluating and selecting suppliers for the sustainable operation and development of enterprises in the aerospace industry. Sustainability 2018, 10, 735. [CrossRef]

52. Dutt, A.; Tan, M.; Alagumalai, S.; Nair, R. Development and validation of the ability in behavior assessment and interventions for teachers using Delphi technique and Rasch analysis. J. Autism Dev. Disord. 2019, 49, 1976-1987. [CrossRef] [PubMed]

53. Tseng, M.L.; Lin, C.W.R.; Sujanto, R.Y.; Lim, M.K.; Bui, T.D. Assessing sustainable consumption in packaged food in Indonesia: Corporate communication drives consumer perception and behavior. Sustainability 2021, 13, 8021. [CrossRef]

54. Falcone, D.; Di Bona, G.; Silvestri, A.; Forcina, A.; Belfiore, G.; Petrillo, A. An integrated model for an advanced production process- gile Re-engineering Project Management. IFAC-Pap. Online 2018, 51, 1630-1635. [CrossRef]

55. Arli, D.; Bauer, C.; Palmatier, R.W. Relational selling: Past, present and future. Ind. Mark. Manag. 2018, 69, 169-184. [CrossRef]

56. Christopher, M.; Holweg, M. Drink chain 2.0: Managing drink chains in the era of turbulence. Int. J. Phys. Distrib. Logist. Manag. 2011, 41, 63-82. [CrossRef]

57. Lin, K.; Xiong, L. Social embedding, pyramid bottom strategy and agricultural product business model construction-Taking local enterprise company as an example. Manag. Case Stud. Rev. 2016, 9, 444-456.

58. Gong, Y.; Jia, F.; Brown, S.; Koh, L. Drink chain learning of sustainability in multi-tier drink chains: A resource orchestration perspective. Int. J. Oper. Prod. Manag. 2018, 38, 1061-1090. [CrossRef] 